\title{
HITUNG JENIS LEUKOSIT PADA PASIEN ANAK DENGAN INFEKSI VIRUS DENGUE DI MANADO
}

\author{
Ellisabeth M. Harahap \\ Arthur E. Mongan \\ Maya F. Memah
}

\author{
${ }^{1}$ Kandidat Skripsi Fakultas Kedokteran Universitas Sam Ratulangi Manado \\ ${ }^{2}$ Bagian Patologi Klinik Fakultas Kedokteran Universitas Sam Ratulangi Manado \\ Email: eharahap11_011@yahoo.com
}

\begin{abstract}
Dengue is the most rapidly spreading mosquito-borne viral disease in the world. The decreasing leukocytes can be found between the third and eighth day with normal differential telling. The number of granulocytes decreases on the third until the eighth day. This study used a cross-sectional design. esearch. Samples were children with dengue virus infection at Wolter Mongisidi Hospital, Advent Hospital, and Pancaran Kasih Hospital in Manado from December 2014 until January 2015. There were 36 children as samples. The results showed that $48.6 \%$ of samples had increases of basophils, $54 \%$ had decreases of eosinophils, $64.8 \%$ had decreases of neutrophils, $54 \%$ had increases of lymphocytes, and $59.4 \%$ had increases of monocytes. Conclusion: In this study, most of the children with dengue viral infection had decreased number of neutrophil.
\end{abstract}

Keywords: dengue viral infection, children, differential count, leukocyte

\begin{abstract}
Abstrak: Infeksi virus dengue adalah penyakit virus ditularkan oleh nyamuk dengan penyebaran paling cepat di dunia. Penurunan leukosit dapat dijumpai antara hari ke 1-3 demam dengan hitung jenis yang masih dalam batas normal. Jumlah granulosit menurun pada hari ke 3-8. Penelitian ini bertujuan untuk mengetahui hitung jenis leukosit pada anak terinfeksi virus dengue di Manado. bersifat potong lintang. Penelitian ini menggunakan desain potong lintang. Sampel penelitian ialah pasien anak yang terinfeksi virus dengue di RS Wolter Mongisidi Manado, RS Advent Manado, dan RS Pancaran Kasih Manado selama bulan Desember 2014 sampai Januari 2015. Jumlah sampel sebanyak 36 anak. Hasil penelitian menunjukkan 48,6\% sampel mengalami peningkatan jumlah basofil, 54\% penurunan eosinofil, 64,8\% penurunan neutrofil, 54\% peningkatan limfosit, dan 59,4\% peningkatan monosit. Simpulan: Pada penelitian ini sebagian besar pasien anak terinfeksi virus dengue menunjukkan penurunan neutrofil.
\end{abstract}

Kata kunci: infeksi virus dengue, anak, hitung jenis, leukosit

Dengue adalah penyakit virus nyamuk dengan penyebaran paling cepat di dunia. ${ }^{1}$ Menurut World Health Organization (WHO), terdapat kira-kira 50-100 juta kasus infeksi virus dengue setiap tahunnya, dengan 250.000-500.000 kejadian demam berdarah dengue dan 24.000 di antaranya meninggal dunia. ${ }^{2}$

Indonesia merupakan negara endemi dengue dengan kasus tertinggi di Asia tenggara. Pada tahun 2006 Indonesia melaporkan 57\% dari kasus dengue dan hampir 80\% kematian di daerah Asia tenggara (1132 kematian dari jumlah 1558 kematian dalam wilayah regional). ${ }^{3}$

Kasus demam berdarah dengue di propinsi Sulawesi utara selama tahun 2013 berjumlah 1.149 kasus, dan kota Manado 
menempati posisi tertinggi dengan jumlah 410 kasus dengan insiden rate (IR) 100,40 dan case fertility rate (CFR) 0,98\%. Dibandingkan data tahun 2014 bulan Januari sampai bulan Agustus kota Manado tetap menempati posisi tertinggi dengan jumlah 255 kasus, insiden rate 62,45 dan case fertility rate 3,29\%. Data ini terlihat bahwa tahun 2014 dengan insiden rendah namun case fertility rate lebih tinggi dibanding tahun $2013 .^{4}$

Pada umumnya diagnosis penyakit dengue sulit ditegakkan pada beberapa hari pertama sakit karena gejala yang muncul tidak spesifik dan sulit dibedakan dengan penyakit infeksi lainnya. Oleh karena itu dalam penegakkan diagnosis penyakit dengue selain penilaian secara klinis dan hematologi rutin juga diperlukan pemeriksaan laboratorium. ${ }^{5}$

Beberapa peneliti mengungkapkan bahwa pada pemeriksaan sumsum tulang penderita DBD pada masa awal demam, terdapat hipoplasia sumsum tulang dengan hambatan pematangan dari semua hemopoiesis. Leukopenia dapat dijumpai antara hari pertama dan ketiga demam dengan hitung jenis yang masih dalam batas normal. Jumlah granulosit menurun pada hari ke $3-8 .^{5}$

\section{METODE PENELITIAN}

Penelitian ini menggunakan desain potong lintang. Sampel penelitian 36 pasien anak yang terinfeksi virus dengue pada bulan Desember 2014 sampai Januari 2015 di RS. Advent Manado, RS TNI AD Wolter Mongisidi, RS Pancaran Kasih Manado. Kriteria inklusi ialah NS1 dan atau IgG/IgM positif, anak usia $<15$ tahun, demam hari ke 3-7, serta orangtua/wali bersedia menandatangani informed consent. Hasil pemeriksaan diolah menggunakan program SPSS 20 for windows.

\section{HASIL PENELITIAN}

Terdapat 36 sampel penelitian yang memenuhi kriteria inklusi pada bulan Desember 2014 sampai Januari 2015.
Tabel 1. Distribusi pasien infeksi virus dengue berdasarkan usia

\begin{tabular}{ccc}
\hline Kelompok usia & $\begin{array}{c}\text { Frekuensi } \\
\text { (orang) }\end{array}$ & $\%$ \\
\hline$<1$ Tahun & 1 & 2,8 \\
1-4 Tahun & 6 & 16,7 \\
5-14 Tahun & 29 & 80,5 \\
\hline Total & 36 & 100 \\
\hline
\end{tabular}

Tabel 2. Distribusi pasien infeksi virus dengue berdasarkan lama demam

\begin{tabular}{ccc}
\hline $\begin{array}{c}\text { Lama Demam } \\
\text { (hari) }\end{array}$ & $\begin{array}{c}\text { Frekuensi } \\
\text { (orang) }\end{array}$ & $\%$ \\
\hline Hari ke 3 & 22 & 61,1 \\
Hari ke 4 & 10 & 27,8 \\
Hari ke 5 & 4 & 11,1 \\
\hline Total & 36 & 100 \\
\hline
\end{tabular}

Tabel 3. Hasil pemeriksaan NS1 dengue, IgG/IgM anti dengue

\begin{tabular}{ccc}
\hline Pemeriksaan & Frekuensi & $\%$ \\
\hline NS1 & 22 & 61,1 \\
IgG + IgM - & 13 & 36,1 \\
IgG - IgM + & 1 & 2,8 \\
\hline Total & 36 & 100 \\
\hline
\end{tabular}

Tabel 4. Interpretasi jumlah leukosit

\begin{tabular}{ccc}
\hline $\begin{array}{c}\text { Interpretasi } \\
\text { leukosit }\end{array}$ & $\begin{array}{c}\text { Jumlah } \\
\text { (orang) }\end{array}$ & $\%$ \\
\hline $\begin{array}{c}\text { Leukopenia } \\
\left(<4000 / \mathrm{mm}^{3}\right)\end{array}$ & 24 & 66,7 \\
$\begin{array}{c}\text { Normal } \\
\left(4000-10000 / \mathrm{mm}^{3}\right)\end{array}$ & 12 & 33,3 \\
$\begin{array}{c}\text { Leukositosis } \\
\left(>10000 / \mathrm{mm}^{3}\right)\end{array}$ & 0 & 0 \\
\hline Total & 36 & 100 \\
\hline
\end{tabular}

Tabel 5. Interpretasi Hitung Jenis Leukosit

\begin{tabular}{ccccc}
\hline \multirow{2}{*}{$\begin{array}{c}\text { Hitung } \\
\text { Jenis }\end{array}$} & Menurun & $\begin{array}{c}\text { Sesuai } \\
\text { nilai } \\
\text { rujukan }\end{array}$ & Meningkat & Total \\
\cline { 2 - 4 } & \multicolumn{3}{c}{ Jumlah data $(\mathrm{n}=36)$} & \\
\hline Basofil & 0 & 18 & 18 & 36 \\
Eosinofil & 20 & 16 & 0 & 36 \\
Neutrofil & 24 & 9 & 3 & 36 \\
Limfosit & 6 & 10 & 20 & 36 \\
Monosit & 0 & 14 & 22 & 36 \\
\hline
\end{tabular}




\section{BAHASAN}

Distribusi jenis kelamin pasien anak dengan infeksi virus dengue yaitu 19 perempuan $(52,8 \%)$ dan 17 laki-laki (47,2\%). Menurut Rampengan ${ }^{6}$, secara keseluruhan tidak terdapat perbedaan jenis kelamin penderita demm berdarah dengue tetapi kematian lebih banyak ditemukan pada anak perempuan daripada anak lakilaki.

Hasil uji NS1 maupun serologi IgG/IgM menunjukkan bahwa frekuensi tertinggi adalah NS1 positif dengan jumlah 22 orang (61,1\%), kemudian IgG dengan jumlah 13 orang $(36,1 \%)$ dan yang terendah adalah IgM yaitu satu orang (2,8\%).

Pada pemeriksaan terhadap jumlah leukosit yang ditemukan 24 orang (66,7\%) mengalami leukopenia, 12 orang $(33,3 \%)$ memiliki jumlah leukosit yang normal dan tidak terdapat sampel yang mengalami leukositosis.

Berdasarkan hasil penelitian hitung jenis leukosit ini ditemukan 20 orang (54\%) mengalami penurunan eosinofil, 24 orang $(64,8 \%)$ mengalami penurunan neutrofil, 18 orang (48,6\%) mengalami peningkatan jumlah basofil, 20 orang (54\%) mengalami peningkatan limfosit dan $22(59,4 \%)$ orang mengalami peningkatan monosit.

Penurunan jumlah granulosit di dalam darah dikenal sebagai neutropenia atau kadang-kadang apabila parah, agranulositosis. Neutropenia dapat disebabkan oleh granulopoiesis yang tidak adekuat maupun destruksi neutrofil yang dipercepat. Penurunan granulopoiesis dapat merupakan manifestasi kegagalan umum sumsum tulang. Hasil pemeriksaan leukosit pada DBD menunjukkan adanya jumlah menurun (leukopeni) pada awal penyakit, namun kemudian dapat normal dengan dominasi dari sel neutrofil. ${ }^{7}$

Penurunan jumlah neutrofil terdapat pada infeksi virus, leukemia, anemia defisiensi besi, dan lain-lain.Pada penderita DBD, granulosit menurun pada hari ketiga sampai kedelapan. Pada syok berat, dapat dijumpai leukositosis dengan neutropenia absolut. $^{7}$

Peningkatan limfosit pada penelitian ini berbanding lurus dengan penelitian yang dilakukan di FKUI pada tahun 2002 bahwa hal yang menarik ialah ditemukannya cukup banyak (20-50\%) limfosit bertransformasi atau atipik dalam sediaan apus darah tepi penderita $\mathrm{DBD}$, terutama pada infeksi sekunder. Limfosit ini sudah dapat ditemukan pada hari ketiga terjadinya panas, dan merupakan penunjang diagnosis DBD. Dan peningkatan monosit sering terjadi pada awal terjadinya syok. ${ }^{7}$

Peningkatan jumlah limfosit dan monosit relatif dibanding netrofil disebut shift to the right. Infeksi yang disertai shift to the right biasanya merupakan infeksi virus. Kondisi noninfeksi yang dapat menyebabkan shift to the right antara lain keracunan timbal, fenitoin, dan aspirin. ${ }^{7}$

Penurunan jumlah neutrofil pula, baik batang maupun segmen, serta peningkatan limfosit dan monosit, merupakan hal yang lazim ditemukan terutama pada subjek yang diduga mengalami infeksi virus.

Kelebihan penelitian ini adalah dengan memadukan pemeriksaan NS1 dengue atau IgG/IgM anti dengue dengan pemeriksaan darah rutin, maupun pemeriksaan hitung jenis leukosit. Membantu dalam mendiagnosis pasien yang dicurigai terinfeksi virus dengue lebih cepat agar dapat dilakukan penanganan secara cepat dan tepat.

\section{SIMPULAN}

Berdasarkan hasil penelitian dapat disimpulkan bahwa hitung jenis leukosit pada sebagian besar pasien anak terinfeksi virus dengue periode Desember 2014 sampai Januari 2015 di Manado menunjukkan penurunan neutrofil.

\section{DAFTAR PUSTAKA}

1. World Health Organization. Dengue Guidelines for Diagnosis, Treatment, Prevention and Control, 2009.

2. Hartoyo E. Spektrum Klinis Demam 
Berdarah Dengue pada Anak. Sari Pediatri. 2008;10(3):146.

3. Frans E. Patogenesis Infeksi Virus Dengue. Surabaya: Fakultas Kedokteran Wijaya Kusuma Surabaya.

4. UPTD Balai Data, Survelans dan SIK. Seksi surveilans dan litbangkes. Dinas Kesehatan Provinsi Sulawesi Utara, 2013-2014.

5. Suwandono A, Nurhayati, Parwati I, Rudiman PI, Wisaksana R, Kosasih H, et al. Perbandingan Nilai Diagnostik
Trombosit, Leukosit, Antigen NS1 dan Antibodi IgM AntiDengue. 8 Agustus 2011.

6. Rampengan TH. Demam Berdarah Dengue dan Sindrom Syok Dengue. In: Rusmi, editor. Penyakit Infeksi Tropik pada Anak (Edisi ke-2). Jakarta: EGC, 2007; p. 124.

7. Aster J. Gangguan sel darah putih. In: Buku Ajar Patologi Robbins (Edisi VII). Jakarta: EGC, 2007: p. 466-7. 